\title{
HAMBATAN PENYELESAIAN SENGKETA TRANSFER PRICING MELALUI MUTUAL AGREEMENT PROCEDURE (MAP) DI INDONESIA
}

\author{
Muhammad Ilham ${ }^{1 *}$, Budiasih Widiastuti $^{2)}$ \\ ${ }^{1)}$ muhammadilham0291@gmail.com, Politeknik Keuangan Negara STAN \\ b)budiasihw@pknstan.ac.id, Politeknik Keuangan Negara STAN \\ *penulis korespondensi
}

\begin{abstract}
This research aims to find out what are the fundamental problems faced in resolving the dispute over Transfer Pricing (TP) through MAP in Indonesia. This research was conducted with qualitative methods in order to observe the phenomena that occur in MAP. The data used are, primary data in the form of in-depth interviews and secondary data in the form of data and information obtained from books, journals, reports, research results, and regulations. The results of this study indicate that the obstacles found in resolving TP corrections through MAP in Indonesia are generally divided into internal obstacles, which are barriers originating from the Directorate General of Taxation (DGT) itself and external obstacles, which are obstacles originating from outside the DGT. Internal barriers consist of Human Resources (HR), Finance (Budget), and Information Technology (IT). While external barriers consist of obstacles from partner countries, communication or language, barriers from taxpayers, and regulation.
\end{abstract}

Keywords: Transfer pricing; MAP; internal obstacles; external obstacles

\begin{abstract}
Abstrak
Penelitian ini bertujuan untuk mengetahui apa sebenarnya permasalahan mendasar yang dihadapi dalam penyelesaian sengketa koreksi Transfer Pricing (TP) melalui MAP di Indonesia. Penelitian ini dilakukan dengan metode kualitatif dalam rangka mengamati fenomena yang terjadi pada praktik penyelesaian MAP. Data yang digunakan yaitu, data primer berupa hasil wawancara terstruktur dan data sekunder berupa data dan informasi yang diperoleh dari buku, jurnal, laporan, hasil penelitian, dan peraturan yang diterbitkan oleh pemerintah. Hasil penelitian ini menunjukkan bahwa hambatan yang terdapat di dalam penyelesaian sengketa koreksi TP melalui MAP di Indonesia secara umum terbagi atas hambatan internal yaitu hambatan yang berasal dari dalam Direktorat Jenderal Pajak (DJP) dan hambatan eksternal yaitu hambatan yang berasal dari luar DJP. Hambatan internal terdiri atas Sumber Daya Manusia (SDM), Keuangan (Budget), dan Teknologi Informasi (TI). Sedangkan hambatan eksternal terdiri atas hambatan dari negara mitra, hambatan komunikasi atau bahasa, hambatan dari Wajib Pajak (WP), dan hambatan dari regulasi.
\end{abstract}

Kata kunci: Penentuan harga transfer; MAP; hambatan internal; hambatan eksternal

\section{PENDAHULUAN}

Pelayananan administrasi perpajakan yang baik mampu menjadi magnet untuk meningkatkan kepatuhan perpajakan setiap warga negara. Pajak yang dibayarkan oleh setiap individu selanjutnya dikelola oleh negara agar dapat membiayai kebutuhan pelayanan publik. Supramono dan Damayanti $(2005,2)$ dalam buku Perpajakan Indonesia menyebutkan sesungguhnya fungsi pajak tidak hanya sebagai sumber penerimaan negara, namun juga memiliki fungsi mengatur, dengan pengertian pajak sebagai alat untuk mengatur atau melaksanakaan kebijakan negara di bidang sosial dan ekonomi.

Kemajuan yang pesat dalam teknologi, transportasi, dan komunikasi memberikan kemudahan bagi perusahaan multinasional dalam menempatkan usaha mereka di negara manapun di belahan dunia (Kurniawan, 2015). Salah satu alat yang dapat digunakan untuk menilai kemajuan dalam bidang Teknologi Informasi (TI) dan komunikasi adalah melalui IPTIK. IP-TIK menggambarkan tingkat pembangunan teknologi informasi dan komunikasi di suatu negara.

Adapun, Perkembangan IP-TIK Indonesia mengalami peningkatan dari tahun ke tahun. Sebagaimana data yang diperoleh dari www.bps.go.id menunjukkan bahwa IP-TIK Indonesia 


\section{EDUCORETAX}

Volume 2 No. 1, 2022

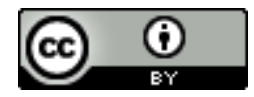

tahun 2015 yaitu sebesar 3,88 yang kemudian meningkat di tahun 2016 menjadi sebesar 4,34 dan meningkat lagi di tahun 2017 menjadi sebesar 4,99 pada Skala 0-10. Hal ini menunjukkan bahwa Indonesia memiliki potensi dan kemajuan pembangunan TIK yang lebih optimum serta memiliki tendensi untuk terus meningkat ke depannya.

Peningkatan IP-TIK juga berpotensi untuk menarik investasi asing langsung di Indonesia karena menurut Kurniawan $(2015$, 1), kemajuan yang pesat dalam teknologi, transportasi, dan komunikasi memberikan kemudahan bagi perusahaan multinasional dalam menempatkan usaha mereka di negara manapun di belahan dunia. Untuk itu, peningkatan potensi tersebut harus pula diimbangi dengan peningkatan pelayanan dan administrasi pendukung, termasuk pelayanan dan administrasi dalam bidang perpajakan, khususnya perpajakan lintas negara.

Permasalahan menjadi cukup sulit dan rumit ketika individu tersebut sudah mulai melakukan kegiatan bisnis atau aktivitas ekonomi di negara yang berbeda. Kemajuan dalam dunia perdagangan telah menyebabkan sebuah permasalahan perpajakan, khususnya terhadap pajak penghasilan, yaitu penentuan harga transfer (transfer pricing).

Berdasarkan Pasal 32A Undang-Undang Pajak Penghasilan, pemerintah berwenang untuk melakukan perjanjian dengan pemerintah negara lain dalam rangka penghindaran pajak berganda dan pencegahan pengelakan pajak. Secara umum, Wajib Pajak (WP) di Indonesia memiliki tiga alternatif sarana yang dapat dipergunakan untuk menghadapi sengketa terkait dengan koreksi TP. Ketiga alternatif sarana itu adalah mengajukan prosedur persetujuan bersama (Mutual Agreement Procedure/MAP), menempuh kesepakatan harga transfer (Advance Pricing Agreement/APA) atau mengajukan banding ke Pengadilan Pajak hingga peninjauan kembali ke Mahkamah Agung (news.ddtc.co.id, 3 Juni 2016). Selanjutnya, penelitian ini akan berfokus pada penyelesaian sengketa koreksi TP melalui sarana MAP.

MAP merupakan alternatif bagi Wajib Pajak untuk menyelesaikan sengketa yang menimbulkan pemajakan berganda, atau apabila terdapat indikasi bahwa tindakan otoritas Negara Mitra menyebabkan pengenaan pajak yang tidak sesuai dengan P3B. Wajib Pajak dapat mengajukan permohonan asistensi kepada Direktur Jenderal Pajak sebagai Competent Authority (CA) atas sengketa yang timbul dari pemajakan berganda dengan Negara Mitra P3B antara lain berasal dari penyesuaian akibat koreksi transfer pricing yang tidak sesuai dengan peraturan dalam P3B (Suparman, 2016).

Di dalam Pasal 25 ayat (1) OECD Model maupun UN Model disebutkan ketentuan sebagai berikut. Pertama, apabila subjek pajak orang pribadi dan badan dikenakan pajak atau akan dikenakan pajak yang tidak sesuai dengan ketentuan P3B, subjek pajak tersebut dapat mengajukan MAP. Kedua, MAP adalah solusi (remedi) penyelesaian sengketa "spesial" di luar ranah penyelesaian sengketa domestik, seperti keberatan atau banding. MAP dianggap spesial karena merupakan proses konsultasi dan bukan litigasi. Ketiga, MAP tidak dimaksudkan untuk mencabut hak wajib pajak pada penyelesaian sengketa domestik. Keempat, pengajuan MAP dilakukan oleh subjek pajak kepada otoritas yang berwenang untuk menyelesaikan sengketa tersebut di negara tempat subjek pajak tersebut terdaftar sebagai subjek pajak dalam negeri. Terakhir, pengajuan MAP harus dilakukan dalam kurun waktu 3 tahun sejak pemberitahuan pertama yang menghasilkan pemajakan yang tidak sesuai dengan ketentuan-ketentuan yang terdapat dalam P3B yang telah disepakati. Pada umumnya pemberitahuan pertama (first notification) dapat diartikan sebagai surat ketetapan pajak atau surat pemberitahuan hasil pemeriksaan (Darussalam et al., 2013, 618-619). 


\section{EDUCORETAX}

Volume 2 No. 1, 2022

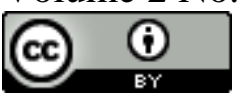

Berdasarkan laporan statistik MAP untuk tahun 2016 s.d. 2018 dari data internal DJP, Indonesia mengalami peningkatan jumlah kasus TP yang menggunakan sarana MAP sebagai berikut.

Tabel 1. Penyelesaian Kasus Koreksi Transfer Pricing melalui MAP di Indonesia Tahun 2016 s.d. 2018

\begin{tabular}{|c|c|c|c|c|}
\hline Tahun & $\begin{array}{c}\text { Kasus Sebelum 1 } \\
\text { Januari }\end{array}$ & $\begin{array}{c}\text { Kasus Dimulai } \\
\text { sejak 1 Januari }\end{array}$ & Kasus Selesai & $\begin{array}{c}\text { Kasus yang } \\
\text { Belum Selesai }\end{array}$ \\
\hline 2016 & 23 & 9 & 5 & 27 \\
\hline 2017 & 18 & 22 & 7 & 31 \\
\hline 2018 & 14 & 37 & 14 & 37 \\
\hline
\end{tabular}

Sumber: Diolah dari database internal DJP (2019)

Berdasarkan tabel di atas dapat dilihat bahwa meskipun jumlah kasus yang berhasil diselesaikan melalui MAP jumlahnya terus meningkat setiap tahun, namun, jumlah kasus menunggak yang belum diselesaikan jumlahnya juga semakin meningkat dari tahun ke tahun, yaitu berturut-turut 27 kasus pada tahun 2016, 31 kasus pada tahun 2017, dan menjadi 37 kasus pada tahun 2018.

Apabila dilihat dari peringkat statistik penyelesaian kasus MAP terkait TP di dunia, Indonesia menduduki peringkat ke-18 dari total 48 negara pada tahun 2016 dan turun menjadi peringkat ke-37 dunia pada tahun 2017 dari total 54 negara. Sedangkan untuk tahun 2018, OECD belum me-release data statistik penyelesaian MAP untuk seluruh negara-negara di dunia sehingga tidak dapat diperbandingkan (www.oecd.org). Selain itu, rata-rata setengah dari outcomes MAP di Indonesia dinilai tidak efektif penyelesaiannya.

Terdapat beberapa penelitian yang relevan terkait dengan penelitian ini, di antaranya penelitian oleh Protto (2014) tentang "Mutual Agreement Procedures in Tax Treaties: Problems and needs in developing countries and countries in transition". Penelitiannya menggunakan metode kualitatif eksploratif. Dalam penelitiannya, beliau menyimpulkan bahwa hambatan penyelesaian kasus MAP di negara berkembang terjadi karena beberapa faktor antara lain Sumber Daya Manusia (SDM), anggaran yang ketat, dan negara-negara dalam masa transisi tidak menganggap MAP sebagai prioritas utama.

Selain itu, penelitian mengenai MAP pernah dilakukan oleh Fitriana (2016) dalam tesisnya yang berjudul Implementasi Kebijakan Mutual Agreement Procedure (MAP) di Indonesia berdasarkan BEPS Action Plan 14 OECD. Pendekatan yang digunakan dalam penelitiannya adalah kualitatif deskriptif dengan metode pengumpulan data secara studi literatur dan studi lapangan yang dilakukan dengan wawancara mendalam. Fitriana mengungkapkan bahwa hambatan penyelesaian MAP di Indonesia adalah terkait dengan pengalaman pegawai DJP yang menangani kasus MAP, jangka waktu MAP yang tidak memiliki kejelasan, kerja sama antara wajib pajak dan DJP yang terhalang keinginan masingmasing pihak untuk tidak mau melakukan transaparansi, dan pola pikir negatif antara sesama rekan kerja DJP.

Penelitian yang telah dilakukan oleh Carlos Protto dan Fitriana, berbeda dengan penelitian ini. Pada penelitian Carlos Protto, beliau hanya membahas mengenai hambatan bagi negara berkembang secara umum, bukan secara khusus di Indonesia. Sedangkan, pada penelitian yang dilakukan Fitriana, meskipun membahas mengenai hambatan MAP di Indonesia, namun hambatan tersebut perlu kiranya untuk diteliti kembali dengan kondisi yang ada pada saat ini. Kondisi pada saat Fitriana melakukan penelitian, Direktorat Perpajakan 


\section{EDUCORETAX}

Volume 2 No. 1, 2022

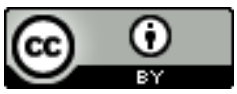

Internasional (PI) baru terbentuk berbeda dengan kondisi saat ini di mana Direktorat PI sudah beberapa tahun terbentuk.

\section{KAJIAN PUSTAKA}

Menurut Hansen dan Mowen (2007, 440), pengertian transfer pricing adalah "the price charged for acomponent by the selling division to the buying division of the same company". Dapat dikatakan bahwa transfer pricing adalah kebijakan dalam penentuan harga penjualan barang/jasa yang terjadi di dalam internal perusahaan. Transfer pricing adalah suatu kebijakan perusahaan dalam menentukan harga transfer suatu transaksi baik itu barang, jasa, harta tak berwujud, atau pun transaksi finansial yang dilakukan oleh perusahaan. Terdapat dua kelompok transaksi dalam transfer pricing, yaitu intra-company dan inter-company transfer pricing. Intra-company transfer pricing merupakan transfer pricing antardivisi dalam satu perusahaan. Sedangkan intercompany transfer pricing merupakan transfer pricing antara dua perusahaan yang mempunyai hubungan istimewa. Transaksinya sendiri bisa dilakukan dalam satu negara (domestic transfer pricing), maupun dengan negara yang berbeda (international transfer pricing) (Setiawan, 2014). Peraturan Menteri Keuangan (PMK) Nomor 49/PMK.09/2019 tentang Tata Cara Pelaksanaan Prosedur Persetujuan Bersama, menyatakan bahwa pengertian Transfer Pricing adalah penentuan harga dalam transaksi antara pihak-pihak yang mempunyai hubungan istimewa.

Menurut Peraturan Pemerintah (PP) Nomor 74 Tahun 2011 tentang Tata Cara Pelaksanaan Hak dan Pemenuhan Kewajiban Perpajakan, Prosedur Persetujuan Bersama (Mutual Agreement Procedure) yang selanjutnya disingkat MAP adalah prosedur administratif yang diatur dalam P3B untuk menyelesaikan permasalahan yang timbul dalam penerapan P3B. Adapun di dalam rumusan Pasal 25 ayat (2) OECD Model dan UN Model disebutkan:

\section{"The competent authority shall endeavour, if the objection appears to it to be justified and if it is not itself able to arrive at a satisfactory solution, to resolve the case by mutual agreement with the competent authority of the other Contracting State, with a view to the avoidance of taxation which is not in accordance with the Convention. Any agreement reached shall be implemented notwithstanding any time limits in the domestic law of the Contracting States."}

Berdasarkan Pasal 25 ayat (2) OECD Model dan UN Model terdapat beberapa karakteristik MAP, yaitu: (a.) Walaupun secara formal MAP dimulai dari pengajuan permohonan oleh subjek pajak yang terkait, prosedur MAP pada dasarnya adalah prosedur antara otoritas yang berwenang. Dengan demikian subjek pajak tidak terlibat dalam proses negosiasi; (b.) MAP tidak memberikan kepastian atas suatu penyelesaian sengketa perpajakan berganda. Dalam Pasal 25 ayat (2) OECD Model maupun UN Model disebutkan bahwa otoritas pajak yang berwenang akan "berusaha" (endeavour) untuk menyelesaikan suatu sengketa perpajakan berganda melalui proses MAP. Akan tetapi, pihak otoritas tidak harus mengambil suatu putusan; (c.) Setiap putusan yang dicapai akan dilaksanakan tanpa memperhatikan pembatasan yang diatur dalam ketentuan domestik di negara yang mengadakan perjanjian. Misalnya apabila terdapat ketentuan daluwarsa di ketentuan domestik suatu negara yang mengadakan perjanjian, ketentuan daluwarsa tersebut tidak dapat membatasi penerapan kesepakatan yang telah dicapai dalam MAP; dan (d.) Tidak terdapat jangka waktu kapan MAP harus diselesaikan sehingga dapat berlangsung secara lama tanpa kepastian hukum bagi subjek pajak yang mengajukan MAP (Darussalam, et al., 2013, 620-621). 


\section{EDUCORETAX}

Volume 2 No. 1, 2022

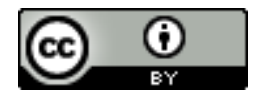

\section{METODE}

Jenis penelitian ini adalah penelitian kualitatif. Penelitian ini dilakukan dalam rangka mengamati fenomena yang terjadi pada praktik penyelesaian MAP serta untuk menginterpretasi dan menganalisis permasalahan sehubungan dengan penyelesaian MAP di Indonesia. Di mana kasus yang terjadi di dalam penyelesaian MAP merupakan fenomena sosial yang memerlukan pemahaman yang mendalam mengenai hal yang diteliti yang tidak dapat dijelaskan melalui penelitian kuantitatif dan analisa data-data statistik.

Ada dua jenis data yang digunakan dalam penelitian ini, yaitu data primer berupa hasil wawancara terstruktur (in-depth interview) dan data sekunder berupa data dan informasi dari buku, jurnal, laporan, hasil penelitian, dan peraturan yang diterbitkan oleh pemerintah. Dalam rangka validasi eksternal, dilakukan triangulasi dengan menggunakan berbagai data dari sumber yang berbeda untuk mengkonfirmasi atau mencapai kejelasan temuan riset. Triangulasi yang digunakan dalam penelitian ini yaitu triangulasi sumber dan triangulasi teknik. Diharapkan dari informasi yang diperoleh dari para informan, maka triangulasi akan lebih mudah terbentuk.

Penentuan sumber data pada orang yang diwawancarai dilakukan secara purposive yaitu dipilih dengan pertimbangan dan tujuan tertentu. (Sugiyono, 2017, 216). Wawancara dilakukan kepada (a.) pemerintah, yaitu Kementerian Keuangan; (b.) akademisi, yang terdiri atas Guru Besar Pajak Universitas Indonesia dan Pengajar pada Pusat Pendidikan dan Pelatihan Pajak; dan (c.) praktisi, yaitu Deputi Director of Center of Indonesia Taxation Analysis dan Konsultan DDTC sebagai representative wajib pajak. Adapun teknik pengumpulan data dilakukan melalui observasi, wawancara, dokumentasi, dan triangulasi/gabungan. Model interaktif Miles dan Hubberman dalam Miles, Huberman, dan Saldana $(2014,10)$ adalah model yang digunakan di dalam teknik analisis data penelitian ini.

\section{HASIL DAN PEMBAHASAN}

Meskipun jumlah penyelesaian sengketa TP melalui MAP di Indonesia mengalami peningkatan, namun perlu dilihat pula apakah jumlah kasus yang berhasil diselesaikan tersebut efektif atau tidak. Kepala Subbidang P3B Amerika dan Eropa, Badan Kebijakan Fiskal (BKF) berpendapat bahwa reviu atas penilaian kinerja penyelesaian MAP perlu untuk dilakukan sebagai cerminan bagi wajib pajak sebelum mereka mengajukan permohonan penyelesaian sengketa TP melalui MAP. Berdasarkan reviu tersebut wajib pajak dapat memperkirakan kemungkinan tentang apakah permohonan mereka akan menghasilkan persetujuan bersama atau tidak. Lebih lanjut, Kepala Subbidang P3B Amerika dan Eropa mengatakan bahwa reviu tersebut juga dilakukan dalam rangka menilai efektivitas penyelesaian sengketa TP melalui MAP. Adapun menurut Kepala Subbidang P3B Amerika dan Eropa, salah satu hal yang dapat dijadikan sebagai penilaian mengenai efektivitas penyelesaian sengketa TP melalui MAP sebagaimana yang ada pada kutipan wawancara berikut.

"Dibilang efektif hanya dua itu, dari yang seluruh yang masuk dibandingkan dengan yang conclude tapi yang conclude itu dibandingkan antara yang 2 tadi dengan conclude yang lain karena efektif hanya dilihat 2 tadi partially relieved atau fully relieved, kalau conclude di luar 2 itu berarti gak efektif karena gak menyelesaikan double tax tadi, contohnya withdraw, withdraw itu bisa mungkin karena WP-nya kok lama nih gak selesai-selesai, yaudahlah saya withdraw aja itu yang kejadian ada yang kayak gitu, yang domestic relieved yang dia udah ada putusan pengadilan berarti kan bukan karena MAP-nya kan.” 


\section{EDUCORETAX}

Volume 2 No. 1, 2022

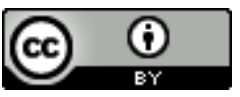

Ketua Komite Pengawas Perpajakan menyatakan bahwa MAP yang efektif itu adalah MAP yang mencapai mutual agreement, dalam arti berapa yang menghasilkan persetujuan bersama yang dapat menyelesaikan sengketa pajak berganda. Perlu diketahui bahwa, terdapat berbagai macam outcome MAP berdasarkan data outcomes MAP yang diperoleh dari data Internal DJP, yaitu: (a.) Denied MAP Access, yaitu permohonan MAP ditolak; (b.) Objection is not justified, yaitu permohonan MAP tidak termasuk hal yang seharusnya dipersengketakan melalui MAP; (c.) Withdrawn by taxpayer, yaitu permohonan MAP ditarik kembali oleh wajib pajak; (d.) Unilateral relief granted, yaitu tercapai kesepakatan unilateral; (e.) Resolved via domestic remedy, telah terselesaikan melalui jalur domestik; (f.) Agreement fully eliminating double taxation/fully resolving taxation not in accordance with tax treaty, yaitu tercapainya kesepakatan untuk mengeliminasi pajak berganda secara penuh sesuai dengan tax treaty; (g.) Agreement partially eliminating double taxation/partially resolving taxation not in accordance with tax treaty, yaitu tercapainya kesepakatan untuk mengeliminasi sebagian pajak berganda sesuai dengan tax treaty; (h.) Agreement that there is no double taxation in accordance with tax treaty, yaitu kesepakatan bahwa tidak ada sengketa pemajakan berganda pada permohonan yang diajukan berdasarkan tax treaty; (i.) No agreement including agreement to disagree, yaitu tidak tercapainya kesepakatan, termasuk kesepakatan untuk tidak sepakat; dan (j.) Any other outcome.

Berdasarkan data yang diperoleh dari database internal DJP, diketahui bahwa tingkat efektivitas outcome dari penyelesaian sengketa koreksi TP melalui MAP di Indonesia tidak begitu memuaskan, pada tahun 2016 outcome yang efektif adalah sebesar 60\%, setelah itu menurun di tahun 2017 menjadi sebesar 42,86\%, dan kemudian meningkat kembali pada tahun 2018 menjadi sebesar 57,14\%. Artinya rata-rata setiap tahun hampir setengah dari outcome tersebut dikatakan tidak efektif. Selain itu berdasarkan data yang diperoleh dari internal DJP diketahui bahwa penyelesaian sengketa koreksi TP di Indonesia yang tidak menghasilkan kesepakatan atau agreement to disagree jumlahnya semakin meningkat dari tahun ke tahun. Semula pada tahun 2016, tidak ada outcome MAP dengan hasil no agreement including agreement to disagree, yang kemudian menjadi 1 outcome di tahun 2017, dan meningkat lagi di tahun 2018 dengan jumlah 3 kasus. Tabel 2 menyajikan penilaian efektivitas kinerja penyelesaian MAP di Indonesia untuk tahun 2016 sampai dengan 2018.

Tabel 2 Efektivitas Kinerja Penyelesaian Sengketa Koreksi TP melalui MAP di Indonesia Tahun 2016 s.d. 2018

\begin{tabular}{|c|c|c|c|c|c|c|c|}
\hline \multirow[b]{2}{*}{$\begin{array}{c}\text { Reporting } \\
\text { Period }\end{array}$} & \multirow[b]{2}{*}{$\begin{array}{c}\text { Year } \\
\text { Category }\end{array}$} & \multirow[b]{2}{*}{$\begin{array}{l}\text { Closed } \\
\text { during } \\
\text { Period }\end{array}$} & \multicolumn{2}{|c|}{ Outcome } & \multirow[b]{2}{*}{$\begin{array}{c}\text { Total } \\
\text { Outcomes }\end{array}$} & \multirow[b]{2}{*}{$\begin{array}{c}\% \\
\text { Effectiveness } \\
\text { per year } \\
\text { category }\end{array}$} & \multirow[b]{2}{*}{$\begin{array}{c}\% \\
\text { Effectiveness } \\
\text { per year }\end{array}$} \\
\hline & & & $\begin{array}{l}\text { Agreement fully } \\
\text { eliminating double } \\
\text { taxation/fully } \\
\text { resolving taxation } \\
\text { not in accordance } \\
\text { with tax treaty }\end{array}$ & $\begin{array}{l}\text { Agreement partially } \\
\text { eliminating double } \\
\text { taxation/partially } \\
\text { resolving taxation } \\
\text { not in accordance } \\
\text { with tax treaty }\end{array}$ & & & \\
\hline \multirow{2}{*}{2016} & Pre-2016 & 5 & 2 & 1 & 3 & $60.00 \%$ & \multirow{2}{*}{$60.00 \%$} \\
\hline & Post -2015 & 0 & 0 & 0 & 0 & $0.00 \%$ & \\
\hline \multirow{2}{*}{2017} & Pre-2016 & 4 & 1 & 0 & 1 & $25.00 \%$ & \multirow{2}{*}{$42.86 \%$} \\
\hline & Post -2015 & 3 & 2 & 0 & 2 & $66.67 \%$ & \\
\hline \multirow{2}{*}{2018} & Pre-2016 & 4 & 4 & 0 & 4 & $100.00 \%$ & \multirow{2}{*}{$57.14 \%$} \\
\hline & Post -2015 & 10 & 4 & 0 & 4 & $40.00 \%$ & \\
\hline
\end{tabular}

Sumber: diolah Penulis dari database internal DJP (2019)

Secara keseluruhan, jika ditinjau dari berapa banyak inventory awal dengan inventory yang menghasilkan outcome, tingkat penyelesaian sengketa koreksi TP melalui MAP di 


\section{EDUCORETAX}

Volume 2 No. 1, 2022

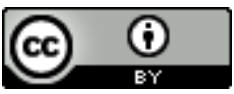

Indonesia pun tidak terlalu memuaskan. Meskipun mengalami peningkatan, namun yang perlu dilihat juga adalah jumlah kasus yang belum terselesaikan, dimana jumlahnya semakin menumpuk dari tahun ke tahun. Untuk jumlah tunggakan kasusnya sendiri berturut-turut dari tahun 2016 sampai dengan 2018, yaitu 27 kasus, 33 kasus, dan menjadi 37 kasus di 2018 seperti ditunjukkan pada Tabel 3 berikut.

Tabel 3 Statistik Penyelesaian MAP untuk Sengketa Koreksi TP di Indonesia Tahun 2016 s.d. 2018

\begin{tabular}{|c|c|c|c|c|c|c|c|c|}
\hline $\begin{array}{c}\text { Reporting } \\
\text { Period }\end{array}$ & $\begin{array}{c}\text { Year } \\
\text { Category }\end{array}$ & $\begin{array}{l}\text { Beginning } \\
\text { Inventory }\end{array}$ & $\begin{array}{c}\text { Requested } \\
\text { during Period }\end{array}$ & $\begin{array}{c}\text { Total } \\
\text { Beginning } \\
\text { Inventory }\end{array}$ & $\begin{array}{l}\text { Closed } \\
\text { during } \\
\text { Period }\end{array}$ & \begin{tabular}{|} 
Ending \\
Inventory
\end{tabular} & $\begin{array}{l}\text { \% of finished } \\
\text { cased per } \\
\text { year category }\end{array}$ & $\begin{array}{c}\% \text { of } \\
\text { finished } \\
\text { cased per } \\
\text { year }\end{array}$ \\
\hline \multirow{2}{*}{2016} & Pre-2016 & 23 & 0 & 23 & 5 & 18 & $21.74 \%$ & \multirow{2}{*}{$15.63 \%$} \\
\hline & Post-2015 & 0 & 9 & 9 & 0 & 9 & $0.00 \%$ & \\
\hline \multirow{2}{*}{2017} & Pre-2016 & 18 & 0 & 18 & 4 & 14 & $22.22 \%$ & \multirow{2}{*}{$17.50 \%$} \\
\hline & Post-2015 & 9 & 13 & 22 & 3 & 19 & $13.64 \%$ & \\
\hline \multirow{2}{*}{2018} & Pre-2016 & 14 & 0 & 14 & 4 & 10 & $28.57 \%$ & \multirow{2}{*}{$27.45 \%$} \\
\hline & \begin{tabular}{|l|} 
Post-2015 \\
\end{tabular} & 19 & 18 & 37 & 10 & 27 & $27.03 \%$ & \\
\hline
\end{tabular}

Sumber: diolah Penulis dari database internal DJP (2019)

Selanjutnya, berdasarkan hasil wawancara yang dilakukan, diketahui bahwa secara umum yang menjadi hambatan dalam penyelesaian sengketa koreksi TP melalui MAP di Indonesia dikelompokkan kepada 2 kategori, yaitu hambatan internal dan hambatan eksternal. Hambatan internal adalah hambatan penyelesaian MAP yang berasal dari dalam DJP itu sendiri, sedangkan hambatan eksternal adalah hambatan yang berasal dari luar DJP. Hambatan internal, terdiri atas SDM, keuangan (budget), dan teknologi informasi. Sementara itu, hambatan eksternal terdiri atas negara mitra, komunikasi/bahasa, wajib pajak, dan regulasi.

Adapun untuk hambatan yang menyatakan bahwa penyelesaian sengketa koreksi TP melalui MAP di Indonesia belum menjadi prioritas, tidak dimasukkan ke dalam hambatan karena berdasarkan pernyataan dari Kepala Subbidang P3B Amerika dan Eropa bahwa saat ini di DJP sudah memiliki dedicated division untuk menangani MAP, jadi dapat dikatakan MAP sudah mendapatkan perhatian dari DJP. Sejalan dengan pernyataan tersebut, Kepala Subdit Pencegahan dan Penanganan Sengketa Perpajakan Internasional pada Direktorat PI juga mengungkapkan bahwa DJP telah memiliki dedicated unit yang khusus menangani sengketa MAP jadi hal itu bukan hambatan bagi Indonesia. Selain itu, pernyataan ini diperkuat dengan bunyi dalam ketentuan Pasal 382 Peraturan Menteri Keuangan Nomor PMK 234/PMK.01/2015 tentang Organisasi dan Tata Kerja Kementerian Keuangan, bahwa telah dibentuk Direktorat baru di DJP yang setara Unit Eselon II, yaitu Direktorat PI, yang kemudian diatur lebih lanjut dalam Surat Edaran Direktur Jenderal Pajak Nomor SE-19/PJ/2016 tentang Tata Cara Pelaksanaan Kegiatan Perpajakan Internasional dimana disebutkan bahwa salah satu kegiatan perpajakan internasional yaitu pencegahan dan penanganan sengketa perpajakan internasional (Prosedur Persetujuan Bersama/Mutual Agreement Procedure dan Kesepakatan Harga Transfer/Advance Pricing Agreement) yang bertindak sebagai pejabat yang berwenang atau Competent Authority (CA) di Indonesia. Adapun nama Subdirektorat yang khusus menangani kasus MAP di DJP adalah Subdirektorat Pencegahan dan Penanganan Sengketa Perpajakan Internasional. Selanjutnya akan dibahas satu persatu mengenai hambatan-hambatan yang terdapat di dalam penyelesaian sengketa koreksi TP melalui MAP di Indonesia. 


\section{EDUCORETAX}

Volume 2 No. 1, 2022

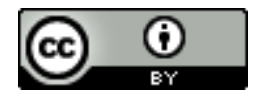

\section{Hambatan Internal}

Hambatan internal yang dimaksud adalah segala sesuatu yang dapat menghambat proses penyelesaian sengketa koreksi TP melalui MAP di Indonesia yang berasal dari internal DJP itu sendiri. Adapun berdasarkan hasil wawancara, hambatan internal yang dihadapi terdiri atas SDM, keuangan, dan TI.

Hambatan pertama yaitu terkait dengan Sumber Daya Manusia (SDM). Kepala Subdit Pencegahan dan Penanganan Sengketa Perpajakan Internasional pada Direktorat PI menyatakan bahwa jika ditinjau dari sisi keahlian dan pengalaman SDM saat ini yang menjadi hambatan justru datang dari pemeriksaan, artinya SDM Pemeriksa Pajak yang masih harus dibenahi. Hambatan terjadi ketika hasil pemeriksaan dari pemeriksa pajak dapat dikatakan kurang berkualitas yang tentu saja hal itu menjadi hambatan pada saat proses penyelesaian MAP atau pada saat akan melakukan negosiasi. Pernyataan senada juga datang dari Senior Manager of International Tax/Transfer Pricing Services DDTC, beliau mengatakan bahwa saat ini kualitas koreksi juga menjadi penghambat dalam proses penyelesaian sengketa TP melalui MAP. Kualitas koreksi yang buruk terkadang membuat pihak yang akan menyelesaikan sengketa menjadi susah untuk memahami koreksi tersebut dan akhirnya bertanya kembali kepada pemeriksa pajak bersangkutan sehingga cukup memakan waktu.

Kepala Subbidang P3B Amerika dan Eropa juga menyatakan hal yang sama bahwa untuk negara berkembang memang masalah utamanya adalah SDM, tapi tidak untuk Indonesia. Mantan pegawai DJP pada Subdirektorat Pencegahan dan Penanganan Sengketa Perpajakan Internasional tersebut mengungkapkan bahwa untuk yang menangani MAP di Indonesia sudah tidak terlalu menjadi masalah karena jika dilihat dari jumlah pegawai yang mengurusi MAP saat ini, jumlahnya sudah banyak dan jika dilihat dari kualitas pun sudah lumayan. Justru beliau mengatakan bahwa selama ini hambatan itu berasal dari lapangan, yaitu pemeriksa pajak. Sebagaimana diketahui bahwa dasar melakukan MAP adalah SKP, dimana SKP merupakan produk pemeriksaan dari pemeriksa pajak. Beliau menyoroti kualitas pemeriksa dalam menghasilkan pemeriksaan yang berkualitas yang justru berdasarkan pemeriksaan yang berkualitas itu lah DJP dapat menghitung penerimaan negara secara lebih pasti karena adanya keyakinan bahwa nilai yang tertera pada SKP yang berkualitas adalah benar sehingga dapat langsung dihitung penerimaan negaranya dan satu hal yang juga bisa menjadi masalah adalah sistem rotasi pegawai DJP yang cukup cepat sehingga jika pegawai yang baru ditempatkan pada Seksi yang menangani MAP belum memiliki pengalaman dalam penyelesaian MAP, pegawai tersebut harus mendapatkan pemahaman melalui pelatihan dan bimbingan terlebih dahulu.

Sementara itu Deputi Direktur Eksekutif Center for Indonesia Taxation Analysis (CITA) justru meragukan kompetensi dari SDM DJP yang menangani kasus MAP. Beliau berpendapat bahwa, SDM yang mengurusi MAP di DJP masih belum banyak pengalamannya sehingga teori-teori mengenai penyelesaian sengketa koreksi TP melalui MAP pun menjadi kurang terasah.

Selanjutnya Guru Besar Ilmu Kebijakan Pajak Universitas Indonesia (UI) menyatakan bahwa DJP harus lebih meningkatkan kualitas SDM, baik SDM yang memang memahami konsep transfer pricing, maupun SDM yang menjadi negosiator di dalam perundingan MAP. Terlebih lagi beliau menekankan bahwa terkait SDM yang melakukan riset terhadap harga wajar di dalam transfer pricing, perlu kiranya melakukan riset dengan mendalam karena jika salah menentukan, akan menciptakan ketidakadilan.

Pengajar Perpajakan pada Pusat Pendidikan dan Pelatihan Pajak (PUSPA) mengatakan bahwa SDM di DJP saat ini tercukupi secara kuantitas. Terlebih para expert yang menangani kasus MAP jumlahnya juga sudah banyak, hambatannya hanya pada bagaimana agar para 


\section{EDUCORETAX}

Volume 2 No. 1, 2022

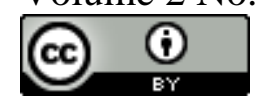

expert tersebut mendapatkan pengakuan secara internasional (Kurniawan, wawancara personal, 26 Maret 2019).

Hambatan internal yang kedua yaitu terkait dengan keuangan (budget). Secara umum hambatan keuangan terjadi karena sifat dari penyelesaian sengketa koreksi TP melalui MAP itu sendiri yang melibatkan dua negara. Para narasumber sepakat bahwa komponen terbesar dalam permasalahan keuangan ini adalah terkait anggaran biaya perjalanan dinas luar negeri. Meskipun menurut Kepala Subdit Pencegahan dan Penanganan Sengketa Perpajakan Internasional pada Direktorat PI, urutan prioritas penyelesaian MAP yaitu, prioritas pertama melalui email, prioritas kedua melalui telepon, prioritas ketiga melalui video call, dan prioritas terakhir adalah face-to-face meeting. Namun, tetap saja pada kasus-kasus tertentu DJP harus melakukan face-to-face meeting, misalnya karena kasus yang terlalu detail sehingga penyelesaian melalui pertemuan langsung adalah pilihan terbaik.

Lebih jauh, Kepala Seksi Pencegahan dan Penanganan Sengketa Perpajakan Internasional III pada Direktorat PI mengatakan bahwa hambatan keuangan merupakan hambatan yang paling besar saat ini. Beliau mengatakan meskipun anggaran untuk perjalanan dinas luar negeri telah disediakan, namun tetap jumlahnya terbatas, sedangkan untuk penyelesaian sengketa melalui MAP ini nantinya frekuensi untuk bertemu dan berunding secara langsung akan lebih meningkat. Beliau mencontohkan, misalnya anggaran perjalanan dinas luar negeri untuk satu tahun anggaran adalah sebesar Rp600.000.000 (Enam Ratus Juta Rupiah), sementara untuk sekali melakukan perjalanan dinas ke Amerika bisa menghabiskan dana sebesar Rp300.000.000 (Tiga Ratus Juta Rupiah) untuk satu tim yang beranggotakan 3 sampai dengan 4 orang, maka akan menjadi hambatan ketika banyak permohonan yang masuk dari banyak negara yang berbeda.

Pernyataan tersebut sejalan dengan pernyataan dari Senior Manager of International Tax/Transfer Pricing Services DDTC yang menyatakan bahwa karena keterbatasan dana akhirnya DJP harus memilih akan mengerahkan dana yang terbatas tersebut kepada WP dari negara yang mana. Begitu juga dengan pernyataan dari Deputi Direktur Eksekutif CITA berikut.

"Sebetulnya concern lebih ke fiskus karena mungkin ini sifatnya juga case by case, ad hoc, dengan sendirinya yang saya tebak mustinya kan tidak ada alokasi dana khusus yang cukup besar setiap tahun mesti dialokasikan ke situ, jadi saya paham ketika mau maju ke MAP ternyata misalnya negaranya dengan Amerika Serikat, bagaimana, siapa yang mau menanggung, tidak mungkin langsung ada budget yang tidak terduga."

Bayangkan saja, jika dalam satu tahun anggaran banyak berkas permohonan MAP yang diterima oleh DJP dan berasal dari berbagai negara, maka tentu saja masalah anggaran dapat menjadi hambatan utama. Berikutnya, Kepala Subbidang P3B Amerika dan Eropa menyampaikan bahwa media MAP adalah konsultasi. Meskipun konsultasi tidak harus bertemu langsung, bisa saja melalui email, teleconference, atau media lainnya, akan tetapi media lain tersebut tetap dinilai tidak efektif jika perundingan yang terjadi adalah perundingan yang sangat 'alot' atau untuk kasus yang sangat membutuhkan pembahasan mendalam. Pada akhirnya, pertemuan langsung yang harus dipilih karena DJP juga tidak bisa memaksakan bahwa pertemuan harus selalu dilakukan di Indonesia sebab perundingan antarnegara untuk membahas MAP itu bersifat resiprokal (bergantian), misalnya tahun ini dilakukan di Indonesia dan tahun depan dilakukan di negara mitra. Walaupun pertemuan dilakukan di Indonesia, negara tetap mengeluarkan dana terkait Biaya Penjamuan Kunjungan Pertemuan dengan Negara Mitra. Guru Besar Ilmu Kebijakan Pajak UI juga mengatakan hal sebagaimana musyawarah akan lebih mudah apabila dilakukan melalui pertemuan langsung. 


\section{EDUCORETAX}

Volume 2 No. 1, 2022

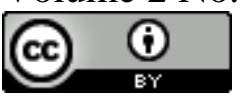

Analis pada Subdit Pencegahan dan Penanganan Sengketa Perpajakan Internasional pun menyampaikan bahwa meskipun dengan adanya bantuan teknologi untuk melakukan perundingan, akan tetapi tetap saja ada kondisi-kondisi dimana kedua negara harus melakukan pertemuan secara langsung, misalnya dalam hal penandatanganan persetujuan bersama. Namun menurutnya semua itu kembali kepada bagaimana kemampuan DJP dalam mengelola anggaran yang terbatas.

Hambatan internal ketiga yaitu hambatan dari Teknologi Informasi (TI). Ketua Komite Pengawas Perpajakan menyatakan bahwa terjadinya sengketa terkait koreksi TP yang akhirnya diselesaikan melalui MAP sebenarnya juga disebabkan oleh belum adanya suatu sistem informasi di DJP yang mampu mengolah data-data perpajakan sehingga dapat dimanfaatkan sebagai suatu alat untuk mengawasi transaksi wajib pajak. Beliau mencontohkan suatu sistem informasi yang ada di negara RRC yang disebut dengan National Revenue System. Sistem tersebut mampu menampung data-data pajak dan diintegrasikan dengan data-data bea cukai. Dengan sistem tersebut, Direktorat Jenderal Bea Cukai mampu untuk melakukan pelacakan (tracing) terhadap suatu data dan hubungannya dengan negara asalnya sehingga atas sengketa transfer pricing-nya dapat diselesaikan oleh Bea Cukai, sedangkan Indonesia belum memiliki sistem yang seperti itu.

Guru Besar Ilmu Kebijakan Pajak UI mengatakan bahwa Indonesia belum mempunyai big data karena Indonesia belum menggunakan manajemen data sehingga tidak bisa memanfaatkan big data. Tentu saja dengan segala keterbatasan teknologi informasi yang ada ini, Information Technology (IT) di bidang perpajakan dikatakan masih belum begitu hebat atau masih terdapat banyak kelemahan. Oleh karena Indonesia belum bisa memanfaatkan big data, maka terdapat potensi yang dapat menghambat proses penyelesaian sengketa koreksi TP. Beliau mencontohkan, apabila SDM DJP dibantu dengan big data dalam menganalisis suatu koreksi TP, maka DJP lebih dapat mempertanggungjawabkan harga wajar yang telah mereka tentukan berdasarkan analisis big data.

\section{Hambatan Eksternal}

Hambatan eksternal yang dimaksud di sini adalah segala sesuatu yang dapat menghambat penyelesaian sengketa koreksi TP melalui MAP yang berasal dari luar organisasi DJP. Adapun berdasarkan hasil wawancara, hambatan eksternal yang dihadapi hambatan dari negara mitra, hambatan komunikasi atau bahasa, hambatan dari WP, dan hambatan dari regulasi.

Hambatan pertama yaitu hambatan dari negara mitra terjadi karena transfer pricing is not an exact science (OECD, 2010). Permasalahan pertama terkait hambatan yang berasal dari negara mitra adalah karena TP bukanlah ilmu pasti, dimana setiap negara memiliki metodenya masing-masing yang mungkin saja berbeda dengan Indonesia. Sebagaimana salah satu kutipan wawancara dengan Pengajar PUSPA berikut.

“...terkait dengan sengketa permasalahan transfer pricing, banyak hal yang berbeda antarnegara. Misalnya, cara menentukan kewajaran menggunakan ex-ante atau ex-post. Kita di Indonesia menggunakan ex-ante, sedangkan banyak negara menggunakan expost, maka susah untuk ditentukan mana yang wajar, apakah menggunakan price setting atau price testing misalnya gitu."

Kepala Seksi Pencegahan dan Penanganan Sengketa Perpajakan Internasional III pada Direktorat PI juga mengungkapkan hal yang sama karena memang ilmu perpajakan, terutama ilmu TP itu tidak berlaku secara universal. Ada beberapa konsep yang berlaku umum, tapi ada pula beberapa konsep yang tidak semua negara memiliki pandangan atau pemikiran yang sama. 


\section{EDUCORETAX}

Volume 2 No. 1, 2022

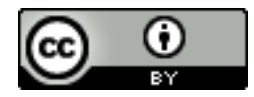

Beliau mencontohkan terkait dengan data pembanding, internal data comparable dan external data comparable. Terkait dengan external comparable, terdapat penerapan yang berbeda di beberapa negara, misalnya ada satu negara yang tidak mengizinkan data pembanding perusahaan yang berasal dari luar negara yang bersangkutan sehingga jika ingin menggunakan data pembanding dari perusahaan lain, harus dipastikan bahwa perusahaan lain tersebut merupakan perusahaan yang berada di negara yang bersangkutan karena ada berbagai pertimbangan seperti faktor geografi, faktor pasar, dan lain sebagainya karena memang ilmu TP memang ilmu yang sangat luas dan sangat komprehensif.

Menurut Senior Manager of International Tax/Transfer Pricing Services DDTC, prosedur administratif negara mitra dapat menghambat proses penyelesaian MAP. Sebagai contoh dengan negara Jepang, di Jepang semua prosedur harus dilakukan formal, jadi setiap koresponden itu harus dilakukan dengan surat. Tentu saja hal ini menghambat penyelesaian MAP karena segala argumen-argumen menjadi lamban, atau dengan kata lain slow response. Berbeda dengan Korea, di Korea konsultasi bisa dilakukan dengan aplikasi whatsapp, sehingga konsultasi bisa lebih santai, meskipun sedang membahas argumen-argumen terkait TP yang sangat teknis sehingga ketika mengadakan pertemuan langsung MAP dapat langsung mencapai persetujuan bersama, akhirnya proses penyelesaian lebih cepat. Selain itu beliau juga menambahkan bahwa hambatan negara mitra juga termasuk pengalaman negara mitra dalam penyelesaian MAP, selain itu termasuk pula pengalaman negara mitra apakah sebelumnya pernah melakukan penyelesaian MAP dengan Indonesia karena biasanya jika belum pernah memiliki pengalaman MAP dengan Indonesia, negosiasinya akan lebih lama.

Sejalan dengan pendapat di atas, Kepala Subdit Pencegahan dan Penanganan Sengketa Perpajakan Internasional mengatakan bahwa sistem atau prosedur domestik di negara lain juga menjadi penghambat proses penyelesaian sengketa koreksi TP melalui MAP. Beliau mencontohkan pada saat terdapat suatu permintaan bilateral APA dengan salah satu negara lain, di saat DJP ingin mengajak negara tersebut berunding, prosedurnya sangatlah rumit. Misalnya negara tersebut mengatakan bahwa harus mendapatkan persetujuan terlebih dahulu dari lembaga tertentu atau dari pejabat tertentu. Selain itu kualitas pemahaman negara mitra terhadap TP juga menjadi hambatan karena menurut Kepala Subdit Pencegahan dan Penanganan Sengketa Perpajakan Internasional akan sangat sulit untuk melakukan negosiasi jika negara mitra tidak memiliki kualitas pemahaman yang baik. Menurut Deputi Direktur Eksekutif CITA jika DJP mengetahui bahwa otoritas pajak negara mitra memiliki tingkat keterbukaan yang tidak terlalu tinggi, maka hal ini akan menjadi salah satu pertimbangan bagi DJP dengan memperhitungkan segala risiko apakah permohonan tersebut akan diselesaikan melalui jalur MAP atau tidak.

Hambatan eksternal yang kedua yaitu terkait dengan hambatan komunikasi/bahasa. Kepala Subdit Pencegahan dan Penanganan Sengketa Perpajakan Internasional, Ketua Komite Pengawas Perpajakan, dan Guru Besar Ilmu Kebijakan Pajak UI sepakat menyatakan bahwa komunikasi atau bahasa dapat menghambat proses penyelesaian sengketa koreksi TP melalui MAP. Berikut adalah salah satu kutipan wawancara dengan Kepala Subdit Pencegahan dan Penanganan Sengketa Perpajakan Internasional.

"Ada negara yang dia itu tidak bisa bernegosiasi melalui telepon karena terhambat bahasa, Bahasa Inggrisnya tidak terlalu bagus intinya. Contohnya, saat menjelaskan ke CA lain pakai bahasa Inggris, mereka juga bukan mother language-nya. Kalaupun kita jelasin ke negara Australia, yang mother language-nya bahasa Inggris kita pun kadang nggak bisa catch-up, kita nggak bisa ngikuti, jangankan bahasa Inggris, bahasa Indonesia saja kalau kita ngomongnya cepet kadang enggak bisa ngikuti." 


\section{EDUCORETAX}

Volume 2 No. 1, 2022

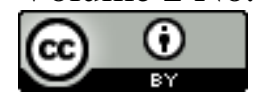

Hambatan eksternal yang ketiga yaitu hambatan yang berasal dari wajib pajak. Pengajar PUSPA berpendapat bahwa hambatan dari wajib pajak adalah terkait pemahaman wajib pajak itu sendiri mengenai prosedur MAP. Menurut Kepala Subdit Pencegahan dan Penanganan Sengketa Perpajakan Internasional dan Analis pada Subdit Pencegahan dan Penanganan Sengketa Perpajakan Internasional, hambatan yang berasal dari wajib pajak umumnya mengenai kemauan wajib pajak untuk melakukan transparansi terkait data dan informasinya atau dengan kata lain wajib pajak enggan melakukan full disclosure. Kepala Subdit Pencegahan dan Penanganan Sengketa Perpajakan Internasional dan Analis pada Subdit Pencegahan dan Penanganan Sengketa Perpajakan Internasional mengatakan bahwa apabila wajib pajak tidak mau transparan terhadap segala data dan informasinya terlebih jika hal tersebut dilakukan wajib pajak karena terdapat tendensi untuk hanya dilakukan pemajakan di negara mitra saja, maka tidak akan tercapai suatu solusi yang baik, bahkan bisa berujung pada agreement to disagree. Padahal dengan demikian, wajib pajak adalah pihak yang sebenarnya paling dirugikan karena putusannya akan dikembalikan kepada SKP sehingga wajib pajak harus membayar pajak sesuai dengan SKP dan akhirnya terkena double taxation. Dalam sebuah kutipan wawancara, Kepala Subdit Pencegahan dan Penanganan Sengketa Perpajakan Internasional mengatakan bahwa bagi Indonesia, hambatan terbesar penyelesaian sengketa koreksi TP melalui MAP adalah berasal dari wajib pajak itu sendiri.

Hambatan eksternal yang keempat yaitu terkait dengan regulasi pemerintah Indonesia. Kepala Seksi Pencegahan dan Penanganan Sengketa Perpajakan Internasional III pada Direktorat PI, Kepala Subbidang P3B Amerika dan Eropa, dan Senior Manager of International Tax/Transfer Pricing Services DDTC secara umum mengatakan hambatan dari regulasi terjadi pada saat wajib pajak melakukan prosedur keberatan atau banding bersamaan dengan prosedur MAP, dimana jika sampai dengan putusan banding diucapkan, belum ada persetujuan bersama yang dihasilkan dari proses perundingan MAP, MAP harus dihentikan. Peraturan yang dimaksud di sini adalah bunyi dari ketentuan Pasal 57 ayat (7) PP Nomor 74 Tahun 2011 yang menyebutkan, "Apabila pelaksanaan MAP dilakukan bersamaan dengan proses banding dan sampai dengan Putusan Banding diucapkan, pelaksanaan MAP belum menghasilkan Persetujuan Bersama, Direktur Jenderal Pajak menghentikan MAP.”

Selain itu, menurut Melani terdapat hambatan lain dalam proses penyelesaian sengketa koreksi TP melalui MAP sebagaimana dalam kutipan wawancara berikut.

“... misalnya udah kadaluarsa nih, yang meriksa otoritas sana, dikoreksi, WP sana induknya, minta corresponding adjustment ke sini...kalau belum ada SKP, belum pernah ada SKP sementara udah lebih dari 5 tahun kita kan gabisa ngapa-ngapain."

Pernyataan ini sejalan dengan Pasal 22 UU KUP yang menyatakan bahwa daluwarsa penagihan pajak adalah 5 (lima) tahun dihitung sejak surat tagihan pajak dan surat ketetapan pajak diterbitkan, serta dapat tertangguh apabila diterbitkan surat paksa, ada pengakuan utang pajak dari WP, diterbitkan SKPKB, atau dilakukan penyidikan tindak pidana di bidang perpajakan.

Sementara itu hambatan dari aspek regulasi lainnya terjadi karena kompleksitas dari regulasi itu sendiri. Hal inilah yang turut menyebabkan masalah ketidakpahaman wajib pajak terhadap prosedur penyelesaian melalui jalur MAP (Kurniawan, wawancara personal, 26 Maret 2019). 


\section{EDUCORETAX}

Volume 2 No. 1, 2022

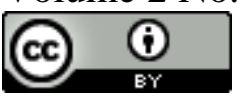

\section{PENUTUP \\ Simpulan}

Berdasarkan pembahasan yang telah diuraikan di atas, dapat disimpulkan hal-hal sebagai berikut. Hambatan penyelesaian sengketa koreksi TP melalui MAP secara umum terdiri atas hambatan internal dan hambatan eksternal. Hambatan internal, terdiri atas Sumber Daya Manusia (SDM), keuangan (budget), dan Teknologi Informasi. Hambatan SDM yang dimaksud yaitu SDM yang berasal dari lapangan, yaitu SDM Pemeriksa Pajak yang menghasilkan pemeriksaan berupa SKP karena memang diakui bahwa pemeriksaan merupakan cikal bakal dari sengketa TP. Adapun masalah keuangan diakui sebagai masalah utama dalam proses penyelesaian sengketa koreksi TP melalui MAP di Indonesia. MAP merupakan suatu sarana penyelesaian sengketa yang mahal karena adanya biaya yang tidak ditemui pada penyelesaian sengketa melalui domestic remedies, terutama untuk komponen biaya perjalanan dinas luar negeri. Sedangkan hambatan di bidang TI terjadi karena DJP belum memiliki suatu sistem informasi yang mampu mengolah big data perpajakan sehingga dapat dimanfaatkan sebagai suatu alat untuk mengawasi transaksi wajib pajak secara cepat dan menyeluruh.

Hambatan eksternal terdiri atas hambatan dari negara mitra, hambatan komunikasi atau bahasa, hambatan dari WP, dan hambatan dari regulasi. Hambatan yang berasal dari negara mitra umumnya disebabkan oleh perbedaan metode yang digunakan dalam penentuan koreksi TP dan prosedur administratif dari negara mitra yang bersangkutan. Hambatan komunikasi/bahasa dapat memperlama proses MAP dan pada beberapa kasus hambatan bahasa mengakibatkan kedua negara harus bertemu secara langsung untuk melakukan proses negosiasi karena tidak semua negara mahir menggunakan bahasa inggris. Hambatan dari WP terutama terkait dengan transparansi di mana WP enggan melakukan full disclosure. Padahal full disclosure merupakan kunci utama penyelesaian sengketa TP melalui MAP yang baik. Sedangkan hambatan dari egulasi domestik terjadi pada saat wajib pajak melakukan prosedur keberatan atau banding bersamaan dengan prosedur MAP atas 1 (satu) SKP, di mana apabila sampai dengan putusan banding diucapkan, belum ada persetujuan bersama yang dihasilkan dari proses perundingan MAP, maka MAP harus dihentikan. Adanya aturan ini secara tidak langsung membuat segala proses yang telah dilakukan di antara kedua negara ini akhirnya tidak menghasilkan kesepakatan apapun karena harus dihentikan.

\section{Saran}

Regulator sebaiknya mengevaluasi aturan yang ada pada saat ini khususnya terkait dengan definisi hubungan istimewa serta pelaksanaan penyelesaian sengketa melalui pengajuan paralel domestic remedies dan MAP. Definisi mengenai hubungan istimewa yang ada pada saat ini dinilai sangat longgar dan mudah untuk dihindari. Selain itu, evaluasi terhadap aturan hubungan istimewa dibutuhkan agar kasus sengketa TP yang terjadi antarnegara yang seharusnya dapat diselesaikan melalui MAP, benar-benar dapat diselesaikan melalui MAP sesuai dengan tax treaty yang ada. Sementara itu, ketidakadilan yang ada di dalam penyelesaian sengketa TP melalui MAP terjadi karena adanya regulasi domestik yang dapat menghentikan proses MAP atau berpotensi menghasilkan putusan banding yang berbeda dengan persetujuan bersama yang telah dicapai. Dalam hal ini, regulator dapat menjadikan interpretasi hubungan istimewa serta praktik penyelesaian sengketa TP melalui pengajuan paralel di beberapa negara sebagai acuan dalam mengevaluasi dan menyusun regulasi yang baru.

Direktorat Jenderal Pajak sebaiknya mengevaluasi dan meningkatkan kompetensi Pemeriksa Pajak dan mulai memikirkan cara-cara yang harus digunakan untuk membuat para expert di bidang TP agar bukan hanya ahli di bidang TP, melainkan juga mendapatkan pengakuan dari dunia internasional. Pengelolaan anggaran yang tersedia khususnya terkait 


\section{EDUCORETAX}

Volume 2 No. 1, 2022

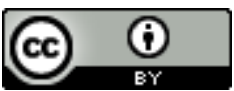

dengan perjalanan dinas luar negeri seharusnya menjadi fokus utama dalam pengelolaannya agar tidak menjadi hambatan dalam penyelesaian MAP. Teknologi informasi di bidang perpajakan juga perlu untuk dimaksimalkan terutama terkait dengan manajemen big data analytics agar penyelesaian sengketa koreksi TP bahkan penetapan dasar harga koreksi TP menjadi lebih baik dan dapat lebih dipertanggungjawabkan. Bagi negara mitra hendaknya dapat menjadikan hasil penelitian ini sebagai cerminan dalam penyelesaian sengketa koreksi TP melalui MAP yang lebih baik ke depannya, salah satunya melalui persamaan interpretasi mengenai hubungan istimewa dan percepatan prosedur administratif.

\section{DAFTAR PUSTAKA}

Darussalam, D. S., \& Kristiaji, B. (2013). Transfer pricing - Ide, strategi, dan panduan praktis dalam perspektif pajak internasional. Danny Darussalam Tax Center.

Fitriana, B. I. (2016). Implementasi kebijakan Mutual Agreement Procedure (MAP) di Indonesia berdasarkan BEPS Action Plan 14 OECD. [Tesis belum diterbitkan]. Universitas Indonesia.

Hansen, D. R., \& Mowen, M. M. (2007). Managerial accounting, $8^{\text {th }}$ edition. Thomson Learning.

Ketentuan Umum dan Tata Cara Perpajakan, Undang-Undang Republik Indonesia Nomor 6 Tahun 1983 sebagaimana telah beberapa kali diubah terakhir dengan Undang-Undang Republik Indonesia Nomor 7 Tahun 2021 tentang Harmonisasi Peraturan Perpajakan. (2021).

Kurniawan, A. M. (2015). Transfer pricing untuk kepentingan pajak. CV. Andi Offset.

Kusumawardani, V. (2016, Juni 3). Pilih banding, MAP, atau APA? DDTC. https://news.ddtc.co.id/analisis-pilih-banding-map-atau-apa-6466.

Miles, M. B., Huberman, A. M., \& Saldana, J. (2014). Qualitative data analysis, a methods sourcebook. SAGE Publications, Inc.

Organisation for Economic Co-operation and Development (OECD). (2010). Commentaries on the articles of the model tax convention.

Organisation for Economic Co-operation and Development (OECD). (2015). OECD/G20 base erosion and profit shifting project, making dispute resolution mechanisms more effective, action 14 - 2015 final report.

Pajak Penghasilan, Undang-Undang Republik Indonesia Nomor 7 Tahun 1983 sebagaimana telah beberapa kali diubah terakhir dengan Undang-Undang Republik Indonesia Nomor 7 Tahun 2021 tentang Harmonisasi Peraturan Perpajakan. (2021).

Protto, C. (2014). Mutual agreement procedures in tax treaties: Problems and needs in developing countries and countries in transition. Kluwer Law International BV.

Setiawan, H. (2014). Transfer pricing dan risikonya terhadap penerimaan negara. Badan Kebijakan Fiskal Kementerian Keuangan.

Suparman, R. A. (2016, Oktober 1). Pajak internasional. Blogspot. http://pajaktaxes.blogspot.com /p/pajak-internasional.html

Supramono \& Damayanti, T. W. (2005). Perpajakan Indonesia-Mekanisme dan perhitungan. Andi.

Tata Cara Pelaksanaan Hak dan Pemenuhan Kewajiban Perpajakan, Peraturan Pemerintah Nomor 74 Tahun 2011. (2011).

Tata Cara Pelaksanaan Prosedur Persetujuan Bersama, Peraturan Menteri Keuangan Nomor 49/PMK.03/2019. (2019). 
EDUCORETAX

Volume 2 No. 1, 2022

(c) (i)

Tata Cara Pelaksanaan Prosedur Persetujuan Bersama (Mutual Agreement Procedure) Berdasarkan Persetujuan Penghindaran Pajak Berganda, Peraturan Direktur Jenderal Pajak Nomor PER-48/PJ/2010. (2010). 